\title{
Radiation Phantom with Humanoid Shape and Adjustable Thickness (RPHAT)
}

\author{
J. Lehmann, R.L. Stern, J. Levy, T. Daly, \\ C.L. Hartmann Siantar, Z. Goldberg
}

This article was submitted to World Congress on Medical Physics \& Biomedical Engineering Sydney, Australia August 23-30, 2003

\section{August 11, 2003}

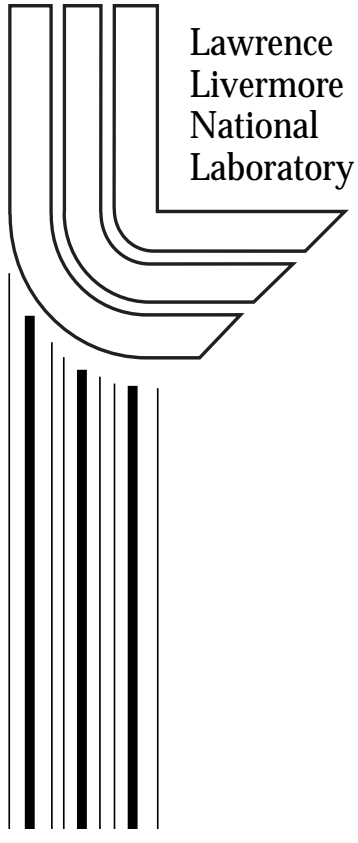




\section{DISCLAIMER}

This document was prepared as an account of work sponsored by an agency of the United States Government. Neither the United States Government nor the University of California nor any of their employees, makes any warranty, express or implied, or assumes any legal liability or responsibility for the accuracy, completeness, or usefulness of any information, apparatus, product, or process disclosed, or represents that its use would not infringe privately owned rights. Reference herein to any specific commercial product, process, or service by trade name, trademark, manufacturer, or otherwise, does not necessarily constitute or imply its endorsement, recommendation, or favoring by the United States Government or the University of California. The views and opinions of authors expressed herein do not necessarily state or reflect those of the United States Government or the University of California, and shall not be used for advertising or product endorsement purposes.

This is a preprint of a paper intended for publication in a journal or proceedings. Since changes may be made before publication, this preprint is made available with the understanding that it will not be cited or reproduced without the permission of the author.

This report has been reproduced directly from the best available copy.

Available electronically at http://www.doc.gov/bridge

Available for a processing fee to U.S. Department of Energy

And its contractors in paper from

U.S. Department of Energy

Office of Scientific and Technical Information

P.O. Box 62

Oak Ridge, TN 37831-0062

Telephone: (865) 576-8401

Facsimile: (865) 576-5728

E-mail: reports@adonis.osti.gov

Available for the sale to the public from

U.S. Department of Commerce

National Technical Information Service

5285 Port Royal Road

Springfield, VA 22161

Telephone: (800) 553-6847

Facsimile: (703) 605-6900

E-mail: orders@ntis.fedworld.gov

Online ordering: http://www.ntis.gov/ordering.htm

OR

Lawrence Livermore National Laboratory

Technical Information Department's Digital Library

http://www.llnl.gov/tid/Library.html 


\title{
Radiation Phantom with Humanoid shape and
}

\author{
Adjustable Thickness (RPHAT) \\ Joerg Lehmann ${ }^{1,2}$, Robin L. Stern ${ }^{2}$, Joshua Levy ${ }^{3}$, Tom Daly ${ }^{1}$, \\ Christine L. Hartmann Siantar ${ }^{1,2}$, and Zelanna Goldberg ${ }^{2}$ \\ 1 University of California - Lawrence Livermore National Laboratory, 7000 East Ave, Livermore, CA 94550 \\ 2 University of California Davis, Cancer Center, 4501 X street, Sacramento, CA 95817 \\ 3 The Phantom Laboratory, 2727 Route 29, Greenwich, NY 12834 \\ jlehmann@llnl.gov
}

\begin{abstract}
A new radiation phantom with humanoid shape and adjustable thickness (RPHAT) has been developed. Unlike the RANDO ${ }^{\circledR}$ Phantom which is a fixed thickness, this newly designed phantom has adjustable thickness to address the variable thickness of realworld patients. RPHAT allows adjustment of the body thickness by being sliced in the coronal direction (as opposed to axial). Center slices are designed such that more sections can be added or removed while maintaining the anthropomorphic shape. A prototype of the new phantom has been successfully used in a study investigating peripheral dose delivery, where the amount of scatter within the patient, and therefore the patient thickness, plays a critical role in dose deposition. This newly designed phantom is an important tool to improve the quality of radiation therapy.
\end{abstract}




\section{Introduction}

The most widely used anthropomorphic phantom for clinical quality control and research in radiation therapy is the RANDO phantom ${ }^{1-6}$. It is constructed with a natural human skeleton cast inside material that is radiologically equivalent to soft tissue. Low-density material is used to simulate lungs. The phantom is axially sliced into $2.5 \mathrm{~cm}$ sections with optional hole grids to hold dosimeters. The two available models correspond to the "standard" man and the "standard" woman. However, in the real-world, many radiotherapy patients do not correspond to those body shapes and sizes, being either overweight as the general American population gets more obese or, in some cases, cachextic as a consequence of their cancer. Dosimetry depends upon the precise amount of patient tissue located along the path length of the particles. Therefore, if the point of interest is located outside of the field, the patient's thickness is a critical factor in accurate dose determination. A new anthropomorphic phantom was developed to address the deficits of a fix thickness phantom. The new phantom is of humanoid shape with an adjustable thickness through the insertion or removal of a variable number of tissue-equivalent slices. A prototype has been built and tested. It provides a robust new model for radiation studies.

\section{Methods and Materials}

The new Radiation Phantom with Humanoid shape and Adjustable Thickness (RPHAT) is a tissue-equivalent anthropomorphic phantom sliced in the coronal direction, which is designed for radiation oncology use. The central slices are shaped to allow a variable number of sections to be inserted while maintaining the 
anthropomorphic shape (Fig 1). A prototype of RPHAT was produced by the manufacturer of the RANDO ${ }^{\circledR}$ Phantoms (The Phantom Laboratory, Greenwich, NY) (Fig. 2, 3). It consists of homogeneous tissue equivalent material of the same type that is used for RANDO® phantoms. "Bones", "lungs" and dosimetry ports were not included in this prototype, but future models could easily accommodate these additional features. In the prototype each of the central slices is $2.5-2.7 \mathrm{~cm}$ thick, with a possibility of inserting up to five of them. Therefore, anthropomorphic phantoms ranging in total thickness from $18.1 \mathrm{~cm}$ to $30.7 \mathrm{~cm}$ can be generated from this single base structure.

RPHAT has been successfully used in a study to investigate the capability of a Monte Carlo system to simulate dose delivery in a multibeam treatment outside of any of the primary beams ${ }^{7}$. Since no primary beam reaches the points of interest in the given situation and therefore all of the dose is due to scatter, the amount of scatter material is crucial. RPHAT allows the determination of the relationship between the scatter dose outside the beam and the patient thickness. Such an investigation would not have been possible with previous phantoms.

\section{Summary}

The new phantom is a valuable addition to the tool chest of medical physicists, which allows quality assurance measurements for a variety of patient thicknesses. For research purposes, RPHAT also allows for the investigation of the influence of patient thickness as an independent dosimetry parameter. Outside of the primary beam scatter dose from within the patient is the main source of radiation to the peripheral tissues. 
Although single-beam measurements can be obtained using a slab-shaped phantom, for multiple beam treatment, it is necessary to use an anthropomorphically shaped phantom to properly model the true scatter pathways. Intrapatient scatter is an important area of research as it represents a significant portion of the dose delivered from an IMRT plan, as well as being a critical component in other radiation related research. Thus, a phantom that is both humanoid and adjustable in thickness is required. RPHAT will help to meet the increasing demand for accurate, patient specific dosimetry for both clinical and research purposes.

\section{Acknowledgements}

This work was performed under the auspices of the U.S. Department of Energy by University of California Lawrence Livermore National Laboratory under contract No. W-7405-Eng-48. This research was supported by the Office of Science (BER), U.S. Department of Energy, Grant No. DE-FG03-01ER63237.

\section{References}

${ }^{1}$ W. L. Saylor and B. L. Adams, "The patient equivalence of the RANDO phantom for cobalt gamma rays," Radiology, 92(1), 165 (1969).

${ }^{2}$ A. Somerwil and H. J. van Kleffens, "Experience with the Alderson Rando Phantom," Br J Radiol, 50(592), 295-6 (1977).

${ }^{3}$ W. Huda and G. A. Sandison, "Estimation of mean organ doses in diagnostic radiology from Rando phantom measurements," Health Phys, 47(3), 463-7 (1984).

${ }^{4}$ V. Y. Golikov and V. V. Nikitin, "Estimation of the mean organ doses and the effective dose equivalent from Rando phantom measurements," Health Phys, 56(1), 111-5 (1989).

${ }^{5}$ O. Esik, T. Bortfeld, R. Bendl, G. Nemeth, and W. Schlegel, "Inverse radiotherapy planning for a concave-convex PTV in cervical and upper mediastinal regions. Simulation of radiotherapy using an Alderson-RANDO phantom. Planning target volume," Strahlenther Onkol, 173(4), 193-200 (1997). 
${ }^{6}$ J. S. Lee, S. L. Dong, and T. H. Wu, "Estimation of organ dose equivalents from residents of radiation-contaminated buildings with Rando phantom measurements," Appl Radiat Isot, 50(5), 867-73 (1999).

${ }^{7}$ J. Lehmann, R. Stern, T. Daly, M. Arnold, C. L. Hartmann Siantar, and Z. Goldberg, "Dosimetry for areas of low dose, outside of the primary radiation therapy beam for a study to assess the effect of low dose ionizing radiation on humans," Int J Radiat Oncol Biol Phys, (submitted). 

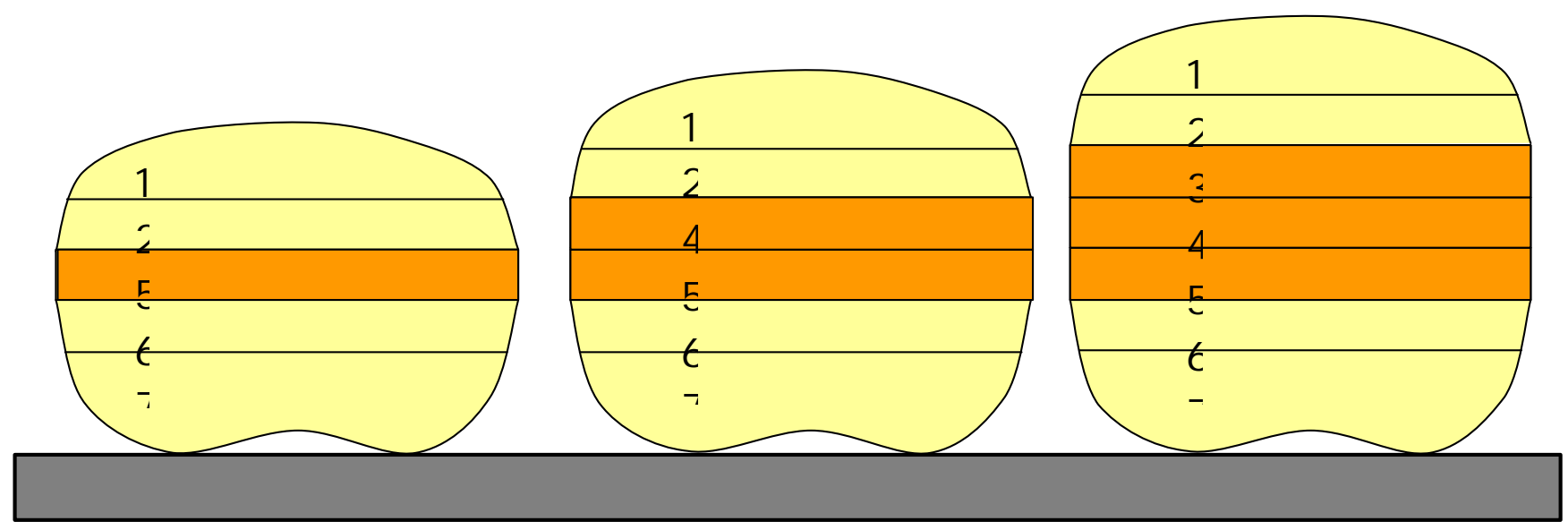

Figure 1: Anthropomorphic phantom with adjustable patient thickness (APAPT). Axial cut display to demonstrate the principle of the optional center sections.

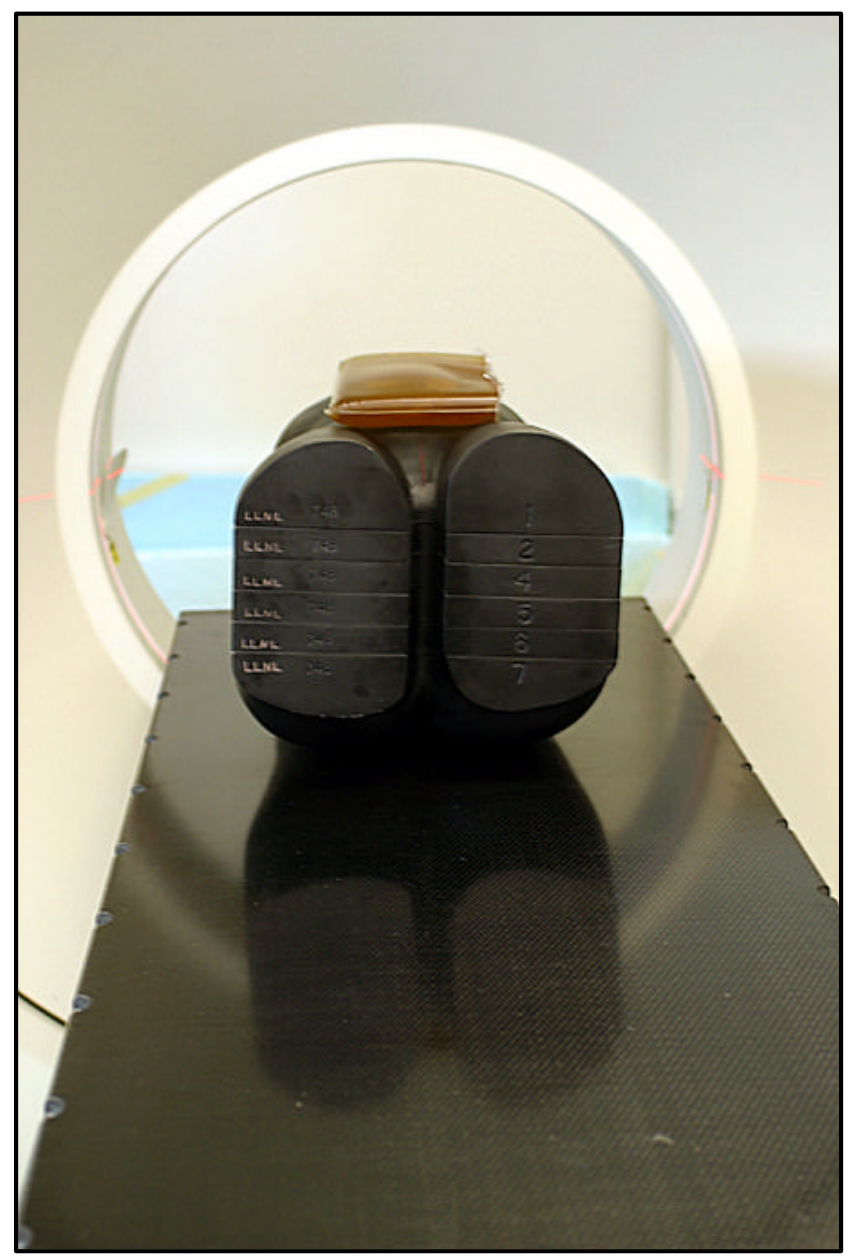

Figure 2: Photos of the RPHAT prototype at the CT scanner with bolus material 


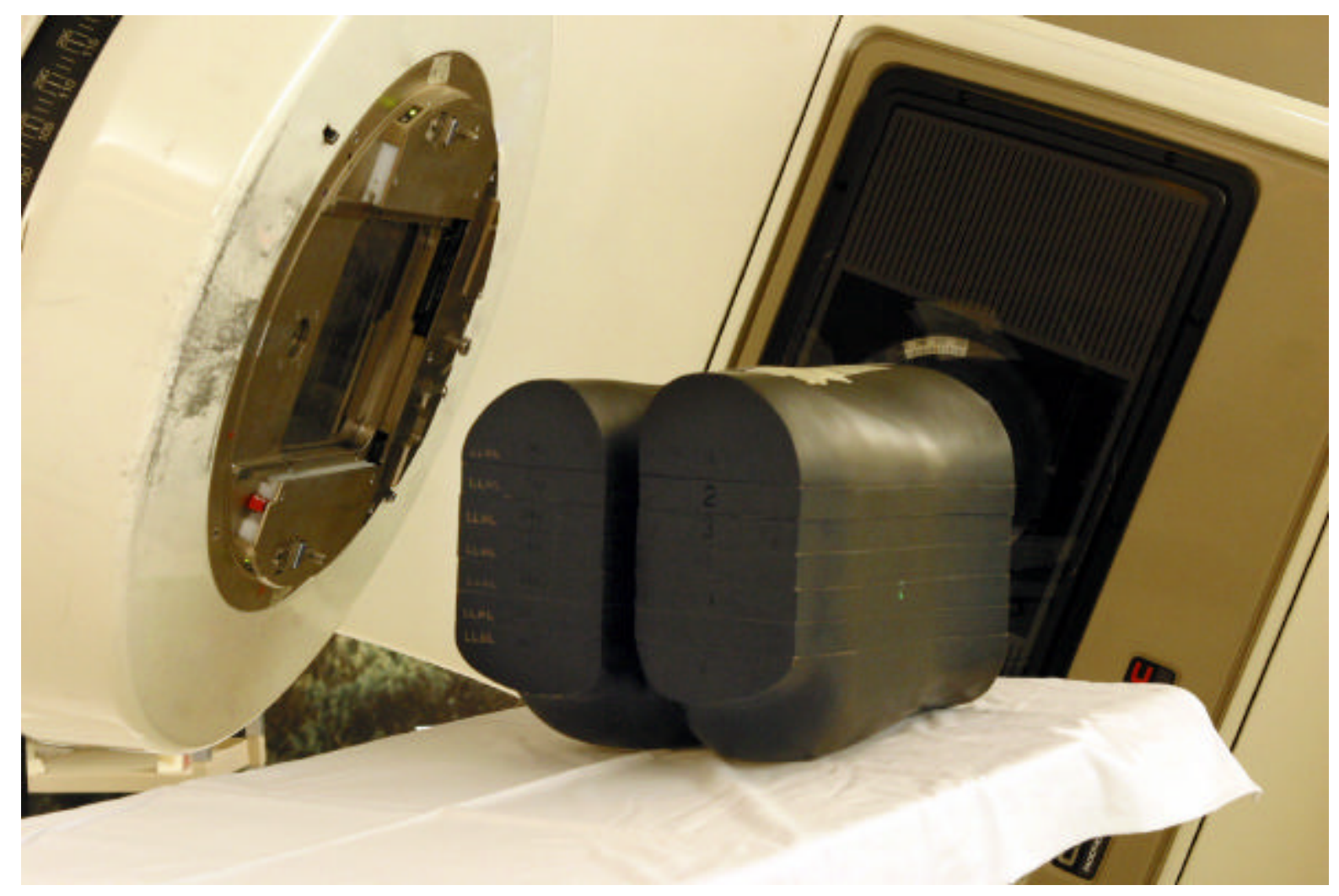

Figure 3: Photo of the RPHAT prototype at the treatment machine. 